\title{
VATS left upper lobectomy after CABG with LIMA-LAD bypass graft
}

\author{
Piotr Gabryel, Cezary Piwkowski, Paweł Zieliński, Wojciech Dyszkiewicz \\ Department of Thoracic Surgery, Medical University in Poznan, Poland
}

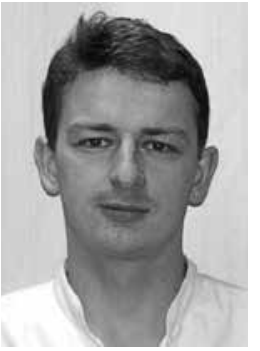

Kardiochirurgia i Torakochirurgia Polska 2016; 13 (1): 52-54

\begin{abstract}
Video-assisted thoracic surgery (VATS) lobectomy has been proven to be a safe operation associated with a low complication rate and good long-term results comparable to those obtained by the thoracotomy approach. During the development of thoracoscopic anatomical lung cancer resections, eligibility criteria for the operation have been gradually extended. Currently, even as complicated cases as bronchial and vascular sleeve resections or pneumonectomies are being performed by VATS. However, minimally invasive surgery after previous coronary artery bypass graft surgery merits special consideration due to the consequences of potential injury to the bypass graft. This is particularly important in the case of VATS left upper lobectomy after left internal mammary artery grafting to the left anterior descending artery bypass.

Key words: video-assisted thoracic surgery, coronary artery bypass.
\end{abstract}

\section{Introduction}

Video-assisted thoracic surgery (VATS) lobectomy has been proven to be a safe operation associated with a low complication rate and good long-term results comparable to those obtained by the thoracotomy approach [1, 2]. During the development of thoracoscopic anatomical lung cancer resections, eligibility criteria for the operation have been gradually extended. Currently, even as complicated cases as bronchial and vascular sleeve resections or pneumonectomies are being performed by VATS [3, 4]. However, minimally invasive surgery after previous coronary artery bypass graft surgery (CABG) merits special consideration due to the consequences of potential injury to the bypass

\section{Streszczenie}

Wideotorakoskopowa (VATS) lobektomia jest bezpieczną, skuteczną onkologicznie i coraz częściej stosowaną metodą leczenia raka płuca. Ze względu na wspólny czynnik etiologiczny, którym jest palenie tytoniu, rak płuca często wspótistnieje z chorobą niedokrwienną serca. Nierzadko chorzy kwalifikowani do operacji anatomicznej resekcji płuca z powodu pierwotnego procesu złośliwego poddani byli uprzednio operacji pomostowania naczyń wieńcowych (coronary artery bypass graft surgery - CABG). Znaczna część z tych chorych, biorąc pod uwagę stopień zaawansowania choroby, mogłaby być zoperowana metodą małoinwazyjną, jednak ze względu na przebytą operację rewaskularyzacji i związane z nią podwyższone ryzyko operacji torakochirurgicznej, operowana jest w sposób klasyczny. W pracy przedstawiono przypadek chorego po CABG z rozpoznanym rakiem płuca, u którego przeprowadzono VATS lobektomię górną lewą. Szczegółowo przeanalizowano aspekty techniczne pozwalające w sposób bezpieczny, bez ryzyka uszkodzenia pomostu aortalno-wieńcowego przeprowadzić operację. Wydaje się, że VATS może być alternatywą dla torakotomii również w przypadku chorych po uprzedniej rewaskularyzacji serca.

Słowa kluczowe: VATS lobektomia, pomostowanie aortalno-wieńcowe.

graft. This is particularly important in the case of VATS left upper lobectomy after left internal mammary artery grafting to the left anterior descending artery bypass.

\section{Case study}

A 58-year-old male was admitted for the surgical treatment of the left lung tumor. He underwent coronary artery bypass grafting (LIMA-LAD) due to myocardial infarction a few years earlier and denied any signs of coronary heart disease afterwards. PET-CT showed increased 18F-FDG uptake in the $20 \mathrm{~mm}$ left upper lobe tumor (SUVmax $=4.5$, stage T1aNOMO). Computed tomography scan of the chest with intravenous contrast showed patent free LIMA-LAD 
bypass surrounded by the left upper lobe pulmonary parenchyma (Fig. 1). Bronchoscopy, electrocardiography and echocardiography were within normal levels. Preoperative pulmonary function test values were as follows: $\mathrm{FEV}_{1} 3.3$ I (95\%) and VC $4.0 \mathrm{I}(85 \%)$

Surgery was performed under general anesthesia with right double-lumen endotracheal tube intubation and selective right lung ventilation. The patient was placed in the lateral decubitus position with flexion of the operating table on the level of the tip of the scapula. Two ports were placed: in the $7^{\text {th }}$ intercostal space in the anterior axillary line and in the $8^{\text {th }}$ intercostal space in the posterior axillary line. A $5 \mathrm{~cm}$-long utility incision was made on the level of the $4^{\text {th }}$ intercostal space anteriorly to the latissimus dorsi muscle. No rib spreader was used.

Extensive pleural adhesions with the anterior mediastinum were noted after introduction of the thoracoscope, particularly of the upper lobe. The bypass graft was visualized. Most of the adhesions were separated using electrocautery, while those in the proximity of the graft were meticulously dissected with regular scissors in order to avoid the thermal injury of the graft. Visual assessment after dissection did not reveal any graft injuries.

The remaining part of the surgery was performed in a conventional manner. Pulmonary ligament and posterior mediastinal pleura of the hilum were dissected. Well-developed interlobar fissure was bluntly dissected and pulmonary artery with its branches was visualized. Superior pulmonary vein, arterial branches to the apical segment, upper lobe bronchus and the remaining vascular branches were sequentially dissected, stapled and cut off with $45 \mathrm{~mm}$-long endostaplers (EndoGIA, Covidien). The upper lobe was then removed from the pleural cavity in a bag. Station $5,7,8$, 10 and 11 lymph nodes were removed. The bronchial stump was submerged under water to check for an air leak. Hemostasis was done in a standard fashion. One $28 \mathrm{~F}$ chest tube was placed in the pleural cavity through the anterior port and connected to the underwater seal. The remaining port and utility incision were closed in a standard fashion. The patient was extubated in the operating room. Total surgery time was 140 minutes and blood loss was $200 \mathrm{ml}$.

The chest tube was removed on the $3^{\text {rd }}$ postoperative day. Due to the atelectasis fiberoptic bronchoscopy was required on the $4^{\text {th }}$ day. The remaining postoperative period was uneventful and the patient was discharged home on the $8^{\text {th }}$ postoperative day.

The final histopathological examination confirmed $25 \mathrm{~mm}$ small cell carcinoma intermediate cell variant (according to WHO classification) with visceral pleura invasion, but no nodal involvement (pT2aNOMO, stage IB). Adjuvant chemotherapy (cisplatin-etoposide) and whole-brain radiotherapy were administered. Follow-up examination 17 months after surgery showed no recurrence.

\section{Discussion}

Due to the common etiological factor - tobacco smoking - lung cancer and coronary heart disease frequently

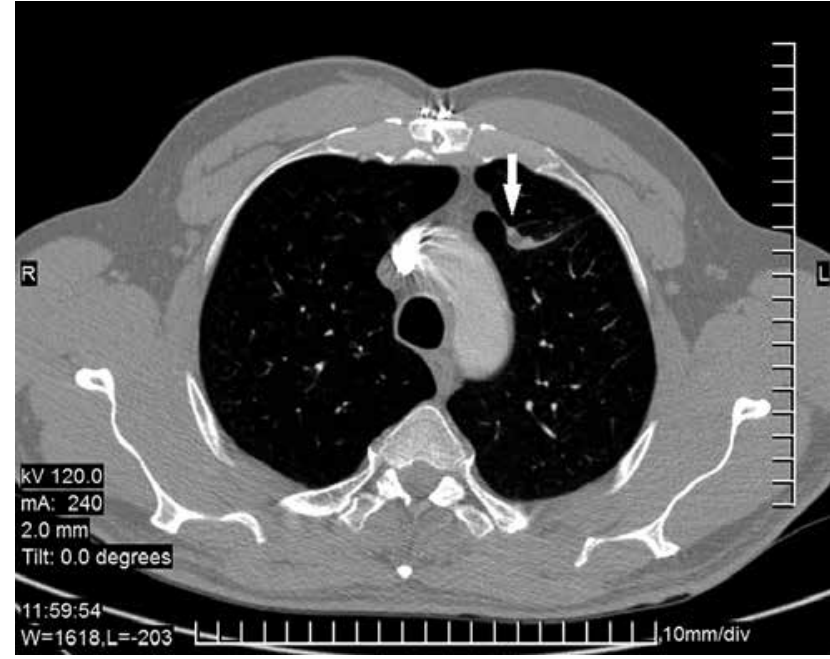

Fig. 1. Computed tomography scan of the chest with intravenous contrast showing patent LIMA-LAD bypass surrounded by the left upper lobe pulmonary parenchyma (arrow)

coexist. Surgical treatment performed in properly qualified patients may provide good long-term results in both diseases. A highly selected group of patients may benefit from simultaneous combined surgery consisting of simultaneous CABG and anatomical pulmonary resection [5]. However, diagnosis of coronary heart disease and CABG often precedes lung cancer diagnosis. Pulmonary resection in such cases may be technically demanding and carries an increased risk of intra-operative as well as post-operative complications. Left upper lobectomy after left internal mammary artery to left anterior descending artery (LIMA-LAD) bypass is probably the most difficult scenario due to the dense adhesions between the visceral pleura of the upper lobe and anterior mediastinum. Dissection of adhesions may potentially cause graft injury and myocardial ischemia.

Postero-lateral or antero-lateral thoracotomy that have traditionally been used as the approaches of choice in such cases offer proper visualization of the graft and allow for its safe dissection. However, significant surgical trauma resulting from long chest wall incision and rib spreading may lead to an increased post-operative complication rate and prolonged hospital stay.

Since the first VATS lobectomy performed by McKenna in 1992, this approach has been widely popularized and accepted [6]. It was proved to have important short-term advantages over thoracotomy (less post-operative pain, shorter hospital stay, improved rehabilitation, potential for better compliance with chemotherapy) and offers longterm results comparable to lobectomy by the thoracotomy approach [7]. Diminished surgical trauma and improved rehabilitation are particularly important in patients with comorbidities and an increased risk of immediate postoperative complications, i.e. after CABG. However, the VATS approach is a technically demanding procedure in such case. Deciding on VATS versus thoracotomy in those patients, capability to obtain radical anatomical pulmonary 
resection and avoidance of bypass graft injury and its catastrophic consequences must be balanced.

There are a few key points in planning and performing VATS lobectomy after CABG. Firstly, surgery should always be preceded by thorough assessment of the CT scan with intravenous contrast to evaluate the course of the graft particularly in terms of its relation to mediastinal pleura and lung parenchyma. Secondly, optimal location of thoracoports and utility incision and the use of the 30 degree optics are crucial for the proper visualization of the full length and all of the surfaces of the graft. In our opinion, it can be even superior to thoracotomy. Thirdly, the choice of instruments used for bypass graft dissection is crucial. Electrocautery may cause graft injury and should be used only in the safe distance from the graft. Separating the graft from the lung by stapling and cutting through the lung parenchyma may be a safe alternative, but crosses anatomical lung borders, decreases the oncological margin and potentially carry an increased risk of local recurrence. Advanced energy devices or vessel-sealing devices, which allow for dissection of the adhesions and coagulation confined to the space between its jaws, seem to be a good option, but not close to the graft. Sharp dissection with endoscopic or open surgical devices, as used in this case does not provide hemostasis or aerostasis, but enable the most accurate dissection. Fourthly, hemostasis of the minor bleeding sites on the graft should be carried out without the use of electrocautery - application of hemostatic material (TachoSil, Floseal, Tisseel) may be an option.

\section{Conclusions}

VATS approach for the left upper lobectomy in cases of the previous LIMA-LAD bypass can be carried out safely by an experienced surgeon after a meticulous preoperative evaluation. However, due to the risk of serious complications in the case of graft injury, including myocardial infarction, protection of the bypass graft is always the priority.

\section{Disclosure}

Authors report no conflict of interest.

\section{References}

1. Cao C, Zhu ZH, Yan TD, Wang Q, Jiang G, Liu L, Liu D, Wang Z, Shao W, Black D, Zhao Q, He J. Video-assisted thoracic surgery versus open thoracotomy for non-small cell lung-cancer: a propensity score analysis based on a multi-institutional registry. Eur J Cardiothorac Surg 2013; 44: 849-854.

2. Łochowski MP, Kozak J. Video-assisted thoracic surgery complications. Videosurgery Miniinv 2014; 9: 495-500.

3. Huang J, Li J, Qiu Y, Xu X, Sekhniaidze D, Chen H, Gonzales-Rivas D, He J. Thoracoscopic double sleeve lobectomy in 13 patients: a series report from multi-centers. J Thorac Dis 2015; 7: 834-842.

4. Piwkowski C, Gabryel P, Kasprzyk M, Dyszkiewicz W. Video-assisted thoracic surgery pneumonectomy: the first case report in Poland. Videosurgery Miniinv 2012; 7: 197-201.

5. Dyszkiewicz W, Jemielity M, Piwkowski C, Kasprzyk M, Perek B, Gąsiorowski $\measuredangle$, Kaczmarek $E$. The early and late results of combined off-pump coronary artery bypass grafting and pulmonary resection in patients with concomitant lung cancer and unstable coronary heart disease. Eur J Cardiothorac Surg 2008; 34: 531-535.

6. McKenna RJ, Houck W, Fuller CB. Video-assisted thoracic surgery lobectomy: experience with 1,100 cases. Ann Thorac Surg 2006; 81: 421-425.

7. Hanna WC, de Valence M, Atenafu EG, Cypel M, Waddell TK, Yasufuku K, Pierre A, de Perrot M, Keshavjee S, Darling GE. Is video-assisted lobectomy for non-small-cell lung cancer oncologically equivalent to open lobectomy? Eur J Cardiothorac Surg 2013; 43: 1121-1125. 